\title{
Article
}

\section{Working Memory, Processing Speed and General Intelligence: Possible Models of Relations with Visuospatial Working Memory Using the Visuospatial Computerized Working Memory Battery (BIMeT-VE)}

\author{
Irene Injoque-Ricle ${ }^{1,2, *}$ \\ Orcid.org/0000-0002-7043-677X \\ Juan Pablo Barreyro ${ }^{1,2}$ \\ Orcid.org/0000-0002-1606-1049 \\ Jesica Formoso ${ }^{2}$ \\ Orcid.org/0000-0003-3062-4036 \\ Débora I. Burin', 2 \\ Orcid.org/0000-0002-2515-719X
}

${ }^{1}$ Consejo Nacional de Investigaciones Cientificas y Técnicas, Buenos Aires, Argentina ${ }^{2}$ Universidad de Buenos Aires, Buenos Aires, Argentina

\begin{abstract}
Working memory is an active memory system serving the realization of complex cognitive tasks. Over the last decades' research has centered on studying the relationship of this memory system or any of its components with different cognitive functions, such as intelligence. The aim of this study is to analyze the relation between visuospatial working memory, processing speed and general intelligence, and the possible mediation role of some of these variables. To carry out this work, two studies were conducted. On Study 1 participated212 Spanish speaking college students, and a Spanish visuospatial working memory battery was designed and validated -the visuospatial Computerized Working Memory Battery (Batería Informatizada de Memoria de Trabajo Viso-Espacial; BIMeT-VE)-. On Study 2 participated 114 Spanish speaking college students, and the relationship among visuospatial working memory, processing speed and general intelligence was analyzed. The results showed that general intelligence is directly supported by the processing speed and to maintain visuospatial information for short periods of time, and indirectly by the ability to concurrently process visuospatial information.
\end{abstract}

Keywords: Visuospatial working memory, processing speed, general intelligence.

Mailing address: Universidad de Buenos Aires, Instituto de Investigaciones, Facultad de Psicología, Gral. Juan Lavalle, 2353, $1^{\circ}$ piso, of. 105 (C1052AAA), Ciudad Autónoma de Buenos Aires, Argentina. Phone: +541149525481. E-mail: iinjoque@psi.uba.ar

This research was supported by the National Scientific and Technical Research Council (CONICET) and the University of Buenos Aires (UBA). 


\title{
Memória de Trabalho, Velocidade de Processamento e Inteligência Geral: Possíveis Modelos de Relacionamento com a Memória de Trabalho Visual e Espacial Usando a Bateria Computorizada de Memória de Trabalho Visual e Espacial (BIMeT-VE)
}

\begin{abstract}
Resumo
A memória de trabalho é um sistema de memória ativo ao serviço da realização de tarefas cognitivas complexas. Nas últimas décadas as pesquisas têm-se centrado em estudar a relação entre a memória de trabalho ou seus subsistemas e outras funções cognitivas, como a inteligência. O objetivo deste estudo é analisar a relação entre a memória de trabalho visuoespacial, a velocidade de processamento e a inteligência geral, e o possível papel mediador destas variáveis. Por esta razão, foram feitos dois estudos. No primeiro desenhou-se e validou-se a Bateria Computorizada de Memória de Trabalho Visual e Espacial (BIMeT-VE) numa amostra de 212 estudantes universitários. No segundo estudo que envolveu 114 estudantes universitários analisou-se a relação entre a memória de trabalho visual e espacial, a velocidade de processamento e a inteligência geral. Os resultados mostraram que a inteligência geral está diretamente associada com a velocidade de processamento e com a habilidade de manter a informação visual e espacial a curto prazo, e indiretamente pela habilidade de processar informação visual e espacial de maneira simultânea.
\end{abstract}

Palavras-chave: Memória de trabalho visual e espacial, velocidade de processamento, inteligência geral.

\section{Memoria de Trabajo, Velocidad de Procesamiento e Inteligencia General: Posibles Modelos de Relación con la Memoria de Trabajo Viso-Espacial Utilizando la Batería Informatizada de Memoria de Trabajo viso-espacial (BIMeT-VE)}

\section{Resumen}

La memoria de trabajo es un sistema de memoria activo al servicio de la realización de tareas cognitivas complejas. En las últimas décadas las investigaciones se han centrado sobre la relación de este sistema de memoria o alguno de sus componentes con diferentes funciones cognitivas, como la inteligencia. El objetivo de este estudio es analizar la relación entre la memoria de trabajo viso-espacial, la velocidad de procesamiento y la inteligencia general, y evaluar el posible rol mediador de alguna de estas variables. Para ello se realizaron dos estudios. En el Estudio 1 se diseñó y validó la Batería Informatizada de Memoria de Trabajo Viso-Espacial (BIMeT-VE) con 212 estudiantes universitarios hispanoparlantes. En el Estudio 2, en el que participaron 114 estudiantes universitarios hispanoparlantes se estudió la relación entre la memoria de trabajo viso-espacial, la velocidad de procesamiento y la inteligencia general. Los resultados mostraron que la inteligencia general está directamente relacionada con la velocidad de procesamiento y con la habilidad de mantener información viso-espacial por breves períodos de tiempo, e indirectamente por la habilidad de procesar concurrentemente información viso-espacial.

Palabras clave: Memoria de trabajo viso-espacial, velocidad de procesamiento, inteligencia general.

Working memory (WM) is an active memory system that has been the center of numerous researches and discussions over the last decades (Alloway, Gathercole, Kirkwood, \& El- liott, 2009; Baddeley, 2010; Broadway \& Engle, 2010; Bull, Espy, \& Wiebe, 2008; Colom, Rebollo, Palacios, Juan-Espinosa, \& Kyllonen, 2004; Cowan, 2010; Currie \& Cain, 2015; Gathercole, 
Alloway, Willis, \& Adams, 2006; Gathercole \& Baddeley, 2014; Oberauer, Süb, Wilhelm, \& Wittmann, 2008; Unsworth \& Engle, 2005). There are theoretical debates regarding its structure: some authors postulate that it is a unitary system (Just \& Carpenter, 1992; Kyllonen \& Christal, 1990; Unsworth, Redick, Heitz, Broadway, \& Engle, 2009), while others maintain a non-unitary approach (Baddeley, 2010; Daneman \& Tardif, 1987; Shah \& Miyake, 1996). In addition, during the past decades, a grate amount of studies involving the implication of WM in several cognitive abilities have been published. Some of the cognitive abilities to which WM is related are intelligence (Colom, Abad, Quiroga, Shih, \& Flores-Mendoza, 2008; Colom et al., 2004; Conway, Kane, \& Engle, 2003; Garlick \& Sejnowski, 2006; Kyllonen \& Christal, 1990; Oberauer et al., 2008), text comprehension (Cain, Bryan, \& Oakhill, 2004; Daneman \& Merikle, 1996; Engle, Cantor, \& Carullo, 1992; Oakhill, Hartt, \& Samols, 2005; Van Dyke, Johns, \& Kukona, 2014), mental arithmetic's (DeStefano \& LeFevre, 2004; Fürst \& Hitch, 2000; Hechet, 2002; Hubber, Gilmore, \& Cragg, 2014), and vocabulary acquisition (Baddeley, 2003, 2010; Baddeley, Gathercole, \& Papagno, 1998).

WM is defined as a storage and concurrent processing system, of limited capacity, serving complex cognitive tasks (Baddeley, 2010; Shah \& Miyake, 1999). One of the most recognized non-unitary models is the one postulated by Baddeley and Hitch (Baddeley, 2010; Baddeley \& Hitch, 1974). The original version of this model states that WM has three subsystems: the central executive, the visuospatial sketchpad and the phonological loop. The central executive controls and regulates the slave subsystems: the visuospatial sketchpad and the phonological loop. It doesn't have storage capacity and is not modality specific. Finally, the phonological loop stores language based information during short periods of time.

Since the 80 's an increasing interest in the relationship between WM and intelligent has guided numerous psychological researches. Most of this research was centered on Spearman's theory of general intelligence (1904).
Spearman asserts that general intelligence includes abilities formed by factors, and that these abilities allow a person to understand, assimilate and use the information in an adequate way. After several and exhaustive factorial analysis Spearman concluded that all the cognitive abilities have a common factor $(\mathrm{g})$, a specific factor (s) and a group factor. Spearman postulates that some cognitive abilities depend more on $g$ than others. The first researchers to study the relation between WM and intelligence were Daneman and Carpenter (1980). They found associations between WM and reading comprehension. Later on, Kyllonen and Christal (1990) found associations between WM and reasoning capacity. One specific study that generated controversy regarding the relation between WM and intelligence was Engle's (2002). On this publication Engle affirms that WM and general intelligence or $g$ are identical constructs. However, previous and posterior studies found that, while there is a consistent relation between both constructs, that relation is not strong enough to assert that they are the same (Broadway \& Engle, 2010; Colom et al., 2008; Conway et al., 2003; Garlick \& Sejnowski, 2006; Oberauer et al., 2008; Unsworth \& Engle, 2005; Unsworth, Fukuda, Awh, \& Vogel, 2014), and no work posterior to Engle's ever found results that would allow researchers to confirm such asseveration. Most studies on the relation of WM and $g$ use only a few measures of WM (e.g. Ackerman, Beier, \& Boyle, 2005; Colom et al., 2008; Oberauer et al., 2008; Süb, Oberauer, Wittmann, Wilhelm, \& Schulze, 2002), or use only measures of fluid intelligence (gf; e.g. Kane \& Engle, 2002; Unsworth \& Engle, 2005; Unsworth et al., 2009). Less studies focus on the relation of WM and crystallized intelligence (gc; e.g. Buehner, Krumm, Ziegler, \& Pluecken, 2006; Haavisto \& Lehto, 2004). Even fewer focus on the relation of the WM components, specially using Baddeley's model, and g, gf or gc. Injoque-Ricle, Barreyro, Formoso and Burin (2015) found a direct relation between visuospatial short term memory (STM) -measured with tasks used to assess the visuospatial sketchpadand $g$, and an indirect relation between visuospatial WM -measured with visuospatial tasks used 
to assess the central executive- and g, mediated by the visuospatial STM in young adults. These relations among these variables were not found within the verbal components of WM.

Another fundamental basic cognitive process to everyday performance on numerous activities is attention. This is a non-unitary process (Posner \& Boies, 1971; Posner \& Rothbart, 1998). Sohlberg and Mateer (1989) postulated a five component model of attention, that are not independent, and might have a hierarchical structure. The components are:

1. Processing speed, which refers to the ease and fluency with which the person responds (Posner, 1975; Posner \& Rothbart, 1998);

2. Sustained attention, which involves the time during which the subject can maintain certain level of performance while carrying out a task;

3. Selective attention, which is defined as a subject's ability to focus on one of two stimulus while suppressing deliberately the processing of distractors (Sohlberg \& Mateer, 1989; Zillmer \& Spiers, 1998);

4. Divided attention, which refers to the ability to carry out more than one activity simultaneously during a period of time (Sohlberg \& Mateer, 1989); and

5. Attentional control, which involves a subject's conscious ability to direct and supervise his or hers attentional resources.

Different WM models highlight the role of attention on WM (Baddeley, 2007; Engle, Kane, \& Tuholski, 1999). Baddeley (2007) mentions this role in the central executive, a system that according to the original model not only activates the representations stored in long term memory and coordinates the slave systems, but is also explained as a controlling attentional system that participates on the maintenance of the attentional focus. Regarding the relationship between WM, processing speed and intelligence, some researchers postulate that processing speed accounts for the relation between WM capacity and fluid abilities (Fry \& Hale, 1996; Jensen, 1998; Kail \& Salthouse, 1994). They suggest that processing information in WM takes time, and the faster the information can be process, the larger the amount of information that can be used in a short period of time. Conway, Cowan, Bunting, Therriault and Minkoff (2002) did a structural equation analysis to determine the predictive capacity of WM, STM and processing speed on fluid intelligence on young adults, using only verbal tasks. They found that the only predictor of fluid intelligence was WM capacity, but they use only direct prediction, and didn't studied if any of the variables had a mediation effect.

The main aim of this study is to analyze the relation between visuospatial WM, processing speed and intelligence, and the possible mediation role of some of these variables. For this purpose, two studies were conducted. The aim of Study 1 is to design and gather validity evidence of the scores estimated by a Spanish visuospatial WM battery: the visuospatial Computerized Working Memory Battery (Batería Informatizada de Memoria de Trabajo Viso-Espacial; BIMeT-VE) which was later used to carry out Study 2. On Study 2, the BIMeT-VE is use as a measure of visuospatial WM to address the main objective of this work, which was mentioned above.

\section{Study 1}

The aim of this study was to develop a visuospatial WM battery that assesses both temporary retention of information and storage and concurrent processing capacity, and to obtain indicators of reliability and validity the battery. In order to obtain an instrument consisting of four tasks -two simple and two complex ones-six tasks were designed -three of each-. For every simple task an equivalent complex version was created.

\section{Method}

\section{Participants}

The sample consisted of 212 Spanish speaking college students of both sexes (114 females $-53.80 \%$ - and 98 males) that participated voluntarily. The subjects were between the ages of 18 and 35, with a mean age of 21.95 years ( $S D$ $=4.01$ ). 


\section{Materials}

All six tasks that assess different aspects of WM were designed to be presented to the subject on a computer screen, and the subject must use the mouse to select different locations on the screen. Each task was designed with nine levels of increasing difficulty, including three trails per level. To move to the next level at least two of the three trails must be correctly solved correctly, if not the task is interrupted. On all the tasks, the participant obtains one point for each correct answer which sums up to the task's total score.

Simple Blocks (Bloques simple). It is a version of the Corsi Blocks task (1972). Nine white blocks are presented on a computer screen unevenly distributed. In each trial, and one by one, the white blocks turn red creating a sequence. The subject must reproduce this sequence by clicking the mouse on the blocks that changed color in the exact order in which they were presented. In the first level only one block changes color, while in the second one the sequence includes two items and so forth. Finally, in the ninth level the sequence includes nine items to remember. Each color block appears for $1000 \mathrm{~ms}$. Figure 1a shows an example from level 4.

Simple Star (Estrella simple). It consists in the presentation on a computer screen of a blue seven-pointed star. A red circle appears at one of its ends, and one end at a time. The subject must remember where the red dot appeared, and the exact order of presentation, indicating the place by clicking on it with the mouse. The first level shows only one red dot, the second one two, and so forth, until the $9^{\text {th }}$ level which shows a sequence of nine items. Each circle shown by 1000 ms. Figure $1 b$ shows an example from level 4 of the task.

Dot Matrix (Matriz de puntos). It consists in the presentation of a white matrix of 16 quadrants on a computer screen. One by one red squares appear in different quadrants of the matrix forming a sequence. After the presentation is complete, the subject should click with the mouse in the quadrants where red squares appeared in the exact order in which they were presented. The number of red squares that appears in the matrix increases one by one according to the level the subject reaches. Each square appears for $1000 \mathrm{~ms}$. Figure 1c shows an example from level 4.

Interference Blocks (Bloques con interferencia). This is the complex version of simple blocks. The procedure differs in that, between the end of the presentation of the sequence of blocks and the subjects' response, a secondary task that lasts $2000 \mathrm{~ms}$. is presented. This task consists on identifying between three polygons which is the most complex -the one with most sides-clicking the mouse on it. Figure 1d shows an example from level 3.

Interference Star (Estrella con interferencia). This is the complex version of Simple Star. The secondary task consists in presenting two analog clocks indicating different times and a digital one showing the same time as one of the previous clocks. The image appears for 2000 ms., and the subject must identify which of the two analog clocks indicate the same time as the digital one by clicking the mouse on it. Figure 1e shows an example from level 3.

Symmetric Span (Amplitud Simétrica). This is the complex version of dot matrix. The secondary task consists in the presentation, for $2000 \mathrm{~ms}$, of a matrix with a design that can be either symmetrical or asymmetrical. The subject must decide by clicking the mouse on one of the words -"symmetrical" or "asymmetrical"that appear at the bottom of the screen. Figure $1 \mathrm{f}$ shows and example from level 3.

\section{Procedure}

The six tasks were administered individually, on a computer screen, in a quiet and well-lit room. The administration order was counterbalanced to avoid the influence of external variables, such as the interference of one task on another, or the fatigue caused by the early tasks, among others.

Data Analysis. To study the internal consistency of each task Cronbach's alpha were estimated. Then, in order to determine the existence of evidence for construct validity, correlations between tasks they were performed, and 


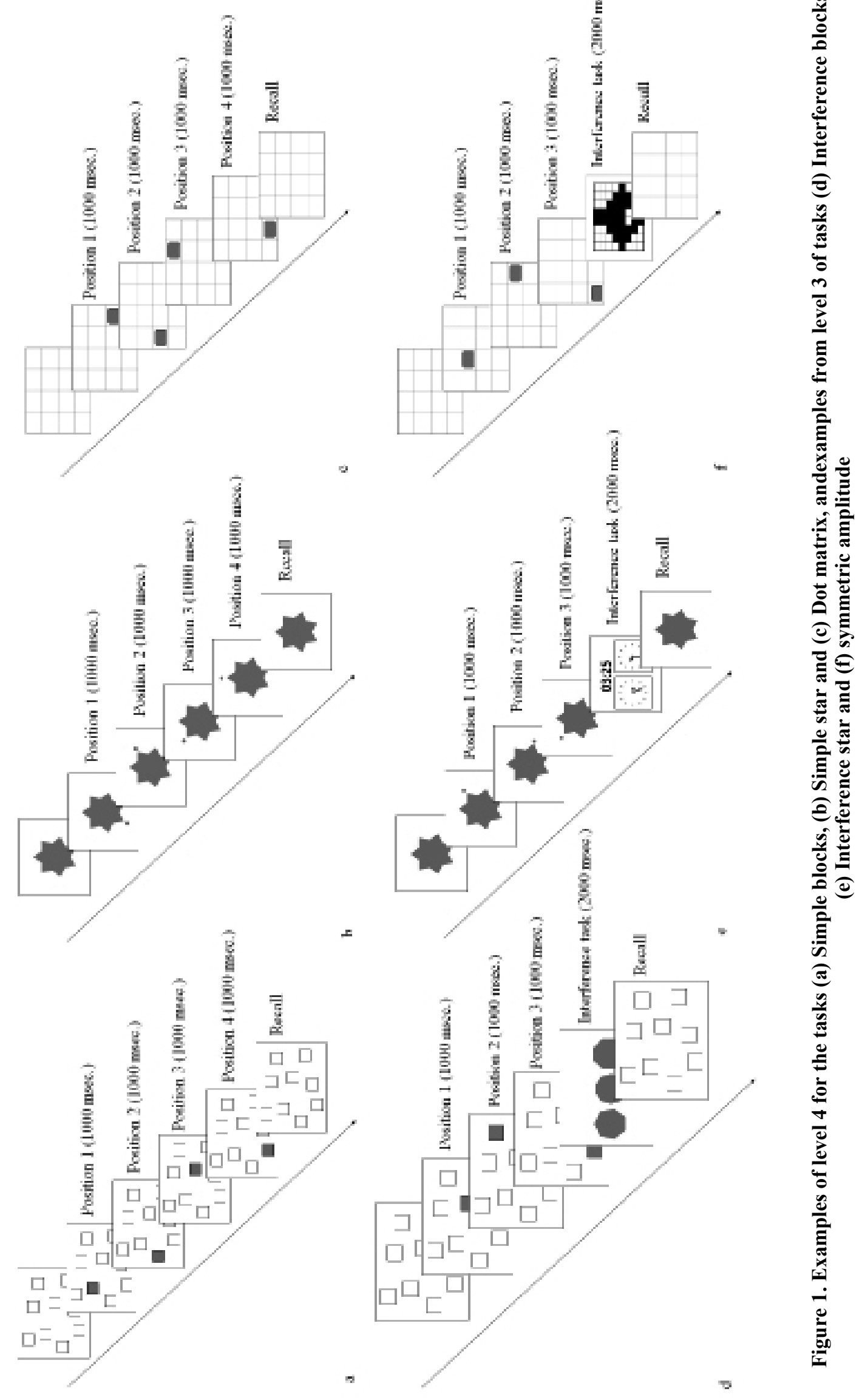


Table 1

Descriptive Statistics, Correlations among the Task Scores and Cronbach's Alpha Values

\begin{tabular}{lccccccccccccc}
\hline & Min. & Max. & Mean & SD & AS & Ku & \multicolumn{6}{c}{$r$} \\
\hline 1. Simple blocks & 3 & 22 & 9.43 & 2.97 & 0.42 & 1.12 & $(.81)$ & $.43^{*}$ & $.39^{*}$ & $.35^{*}$ & $.35^{*}$ & $.37^{*}$ \\
2. Simple star & 3 & 17 & 9.03 & 2.21 & 0.40 & 0.62 & & $(.71)$ & $.24^{*}$ & $.29^{*}$ & $.25^{*}$ & $.24^{*}$ \\
3. Dot matrix & 3 & 16 & 8.29 & 2.76 & 0.43 & -0.08 & & & $(.76)$ & $.24^{*}$ & $.20^{*}$ & $.32^{*}$ \\
4. Interference blocks & 0 & 13 & 4.50 & 2.48 & 0.23 & 0.16 & & & & $(.75)$ & $.43^{*}$ & $.29^{*}$ \\
5. Interference star & 0 & 15 & 3.41 & 2.82 & 1.08 & 1.00 & & & & & & $(.82)$ & $.38^{*}$ \\
6. Symmetric span & 0 & 17 & 3.78 & 2.62 & 0.92 & 1.96 & & & & & & \\
\hline
\end{tabular}

Note. Cronbach's alpha values between parenthesis.

$* p<.01$.

exploratory and confirmatory factor analyzes were conducted, following the Standards for Educational and Psychological Testing, (American Educational Research Association [AERA], American Psychological Association [APA], \& National Council on Measurement in Education [NCME], 2000).

\section{Results}

Table 1 shows the descriptive statistics of the variables included in the study. The internal consistency analysis showed good and very good alpha values (Table 1) while the correlation coefficients for the scores in the six tasks were weak to moderate (according to Evans, 1996), and they were all statistically significant. They are also presented in Table 1 .

An exploratory factor analysis was conducted using the method of principal components with varimax rotation, taking factor loadings below .50 and dual loadings as criteria for elimination. In each analysis it was verified as a prerequisite that the matrix of intercorrelations was adequate to perform this type of analysis and it was confirmed that the matrix was not identical. As a result of successive exploratory factor analysis the tasks symmetric amplitude and dot matrix were excluded. After the first exploratory factor analysis $\left[\mathrm{KMO}=.79, \chi^{2}(15)=227.47\right.$, $p<.01 ; \%$ of explained variance $=58.16]$ the symmetric amplitude task was excluded because its factor loading was .46 on Factor 1 and .49 on Factor 2 (see Table 2). As a result of the second analysis $\left[\mathrm{KMO}=.74, \chi^{2}(10)=168.06, p<.01\right.$; $63.12 \%$ of the item variance were explained] the dot matrix task was eliminated. While it did not present double loading or a factor loading below. 50 (see Table 2), a criterion for the construction of the instrument was that the simple and complex tasks were versions of the same instrument, and dot matrix was the simple storage version of the symmetric amplitude task.

The last exploratory factor analysis $[\mathrm{KMO}=$ $.70, \chi^{2}(6)=130.04, p<.01 ; 71.89 \%$ of the item variance were explained] showed that the four remaining tasks were distributed evenly in two factors, all of them with loadings greater than .50 in a unique factor, one that pooled all the simple storage tasks (simple blocks and simple star) and another that grouped the concurrent processing tasks (interference blocks and interference star; see Table 2).

Finally, a confirmatory factor analysis with the four tasks resulting from the exploratory analysis was conducted. It showed a good adjustment of the data to the model $[\chi 2(1)=0.31$, $p=.58, \mathrm{CFI}=1.00 ; \mathrm{TLI}=1.00, \mathrm{AGFI}=.99$; RMSEA $=.00$ ] (according to Browne \& Cudeck, 1993; Hair, Anderson, Tatham, \& Black, 1998; $\mathrm{Hu}$ \& Bentler, 1999; Schumacker \& Lomax, 1996), with significant factor loadings and a significant correlation between the two factors (see Figure 2). 
Table 2

Factorial Loads and Explained Variance Percentage of the Exploratory Factor Analysis

\begin{tabular}{lcccccc}
\hline & \multicolumn{2}{c}{ Analysis 1 } & \multicolumn{2}{c}{ Analysis 2 } & \multicolumn{2}{c}{ Analysis 3 } \\
\cline { 2 - 7 } & F1 & F2 & F1 & F2 & F1 & F2 \\
\hline Simple blocks & .72 & & .73 & & .74 & \\
Simple star & .64 & & .65 & & .89 & \\
Dot matrix & .79 & & .79 & & -- & -- \\
Interference blocks & & .76 & & .79 & & .79 \\
Interference star & & .85 & & .84 & & .85 \\
Symmetric span & & & -- & -- & -- & -- \\
\hline \% EV & & & & & & \\
\hline
\end{tabular}

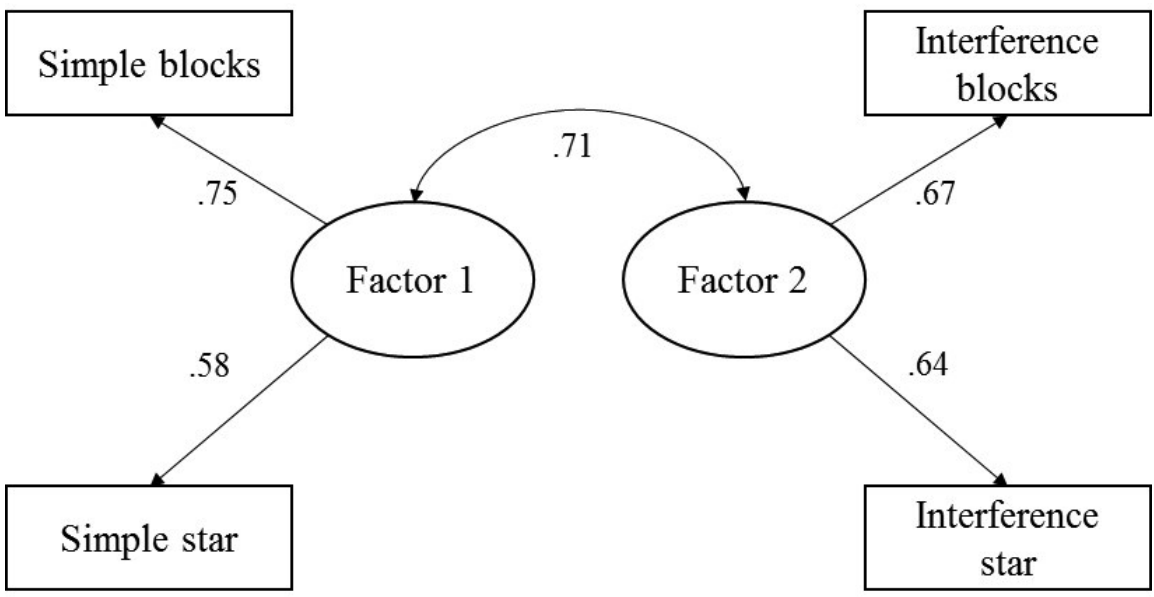

Figure 2. Standardized factor loadings and correlation on the Visuospatial WM two factor model.

\section{Discussion}

The aim of Study 1 was to design and obtain indicators of reliability and validity of a visuospatial WM battery. For this, six tasks were originally created, three that assessed simple storage and three for both storage and concurrent processing of visuospatial information, in order to obtain a battery composed of four tests.

As for the selection of tests, initial correlations analysis showed that the simple storage tasks that best correlated were Simple blocks and Simple star, and in the case of concurrent processing tasks, the interference blocks and interference star tasks. In the subsequent exploratory factor analysis, the symmetrical amplitude task was excluded due to its low factor loading. Afterwards the dot matrix task was excluded because, although it presented adequate factorial load, it was a criterion for the design of the battery that the concurrent processing tasks were complex versions of the simple storage tasks. The third and final exploratory factor analysis, which explained $71.89 \%$ of the variance, resulted in two factors, one that included the simple blocks and simple star tasks, and another that grouped the interference blocks and interference star tasks. 
The four tasks have acceptable reliability for internal consistency. The correlation analysis, the exploratory factor analysis and the confirmatory factor analysis shows that the battery presents evidence for construct validity.

For these reasons, it can be concluded that the BIMeT-VE is a reliable instrument and shows evidence of construct validity, allowing a comprehensively assessment of the visual-spatial aspects of WM.

\section{Study 2}

The aim of this study was to analyze the relation between visuospatial WM and processing speed with $g$, examining the possible role of $\mathrm{WM}$ as a mediator between processing speed and g, and the role of visuospatial STM as a mediator between visuospatial WM and $\mathrm{g}$.

\section{Method}

\section{Participants}

Participated on the study 114 volunteer Spanish speaking college students of both genders ( 72 females $-63.20 \%$ - and 42 males) of the ages of 18 and 35, with a mean age of 21.73 years $(S D=3.92)$.

\section{Materials}

Computerized Visuospatial Working Memory Battery (BIMeT-VE). Includes the following tasks: Simple blocks, Simple star, Interference blocks and Interference star (see Study 1). This battery, along with the Computerized Verbal Working Memory battery (Batería Informatizada de Memoria deTrabajo Verbal - BIMeT-V), comprehensively assesses the components of the WM according to the model proposed by Baddeley and Hitch (Baddeley, 2010; Baddeley \& Hitch, 1974).

Abstract Reasoning (Bennett, Seashore, \& Wesman, 1992). Is part of the Differential Aptitude Test. It measures the non-verbal reasoning ability. A series of graphics items that have a principle of organization are presented and the subject has to choose between five possible options to continue the series. It was administered as a measure of $\mathrm{gf}$.

Verbal Reasoning (Bennett et al., 1992). Along with abstract reasoning is included in the Differential Aptitude Test. It assesses the ability to understand concepts, generate abstractions or generalizations. Incomplete sentences that pose analogies between two terms are presented. Given five options of pairs of words, the subject must choose which one best completes the sentence. It was administered as a measure of gc.

Symbol Search (Wechsler, 2003). It is included in the third edition of Wechsler Adult Intelligence Scale. It measures how easily and fluently a person responds. Is consists in the presentation of two groups of symbols: a target group and a search group. The subject has to identify whether at least one of the symbols of the target group is among the series of symbols of the search group. It was administered as a measure of processing speed.

\section{Procedure}

The administration procedure was the same as in Study 1: the tasks were completed individually, on a computer screen, in a quiet and well-lit room. The administration order was also counterbalanced.

Data Analysis. To determine the degree of relation between the studied variables correlation analysis were performed. In order to study the relation between the variables and the possible mediating role of some of them, a full SEM analyses were conducted, using a bootstrap analysis to test the significance of the indirect effects (Preacher \& Hayes, 2008).

\section{Results}

Table 3 shows the descriptive statistics and the correlations found between the studied variables.

Following the model of relations found between visuospatial WM and $\mathrm{g}$ in a study by Injoque-Ricle et al. (2015) in which visuospatial short-term memory (STM) had a mediating role 
Table 3

Descriptive Statistics and Correlations among the Variables Included on Study 2

\begin{tabular}{|c|c|c|c|c|c|c|c|c|c|c|c|c|c|}
\hline & Min & Max & Mean & $S D$ & AS & $\mathrm{Ku}$ & & & & $r$ & & & \\
\hline & & & & & & & 1 & 2 & 3 & 4 & 5 & 6 & 7 \\
\hline 1. Simple blocks & 1 & 16 & 9.62 & 2.80 & -0.39 & 0.48 & - & $.323^{* *}$ & $.307^{* *}$ & $.214^{*}$ & $.221^{*}$ & $.248^{* *}$ & $.197^{*}$ \\
\hline 2. Simple star & 4 & 15 & 8.94 & 2.05 & 0.39 & -0.01 & & - & $.461^{* *}$ & .173 & $.338^{* *}$ & $.312^{* *}$ & $.284^{* *}$ \\
\hline 3. Interference blocks & 0 & 12 & 4.73 & 2.52 & 0.42 & -0.06 & & & - & $.247^{* *}$ & $.206^{*}$ & .082 & .151 \\
\hline 4. Interference star & 0 & 10 & 2.66 & 2.27 & 1.17 & 0.74 & & & & - & .142 & .073 & $.189^{*}$ \\
\hline 5. Abstract reasoning & 2 & 17 & 12.06 & 2.82 & -0.88 & 0.75 & & & & & - & $.318^{* *}$ & $.454^{* *}$ \\
\hline 6. Verbal reasoning & 4 & 15 & 10.16 & 2.75 & -0.21 & -0.68 & & & & & & - & $.313^{* *}$ \\
\hline 7. Symbol search & 16 & 51 & 32.47 & 7.28 & 0.18 & -0.01 & & & & & & & - \\
\hline
\end{tabular}

$* * p<.01$

$* p<.05$.

between visuospatial WM and g, a model was proposed to analyze the role processing speed in relation to these variables.

Model 1 proposes that processing speed, measured through the Symbol search test, has a direct relation to visuospatial STM, visualspatial WM and g. This model showed good fit indexes $\left[\chi^{2}(10)=9.05, p=.57, \mathrm{CFI}=1.00\right.$; TLI $=1.00, \mathrm{AGFI}=.94 ; \mathrm{RMSEA}=.00]$ (according to Browne \& Cudeck, 1993; Hair et al., 1998; $\mathrm{Hu} \&$ Bentler, 1999; Schumacker \& Lomax, 1996), although no significant direct relationship between processing speed and visuospatial STM, or processing speed and visuospatial WM was found.

Due to the lack of a significant association between processing speed and the two variables of visuospatial WM, a second model was proposed. In this one processing speed has a direct relation with visuospatial WM and $\mathrm{g}$, but its association with visuospatial STM is mediated by visuospatial WM.

Model 2 also shows good fit indexes [ $\chi 2$ (11) $=10.31, p=.50, \mathrm{CFI}=1.00 ; \mathrm{TLI}=1.00, \mathrm{AGFI}$ $=.94 ;$ RMSEA $=.00]$ (according to Browne \& Cudeck, 1993; Hair et al., 1998; Hu \& Bentler, 1999; Schumacker \& Lomax, 1996), and all the associations between variables were significant. Comparing both models there are no significant differences between the fit indexes $(\mathrm{D} \chi 2=1.23$, $p=.26$ ). Following the principle of parsimony, the model selected to explained the phenomenon was the one that contained the fewer relations, which is Model 2. Figure 3 shows Model 2 with the regression weights of the association between variables and the variables' factor loadings that are saturated by the latent factors. Regarding the indirect effects, the Symbol search test showed a significant indirect effect on visuospatial STM mediated by visuospatial WM $(\beta=.36, p=.01)$ and on $\mathrm{g}$, mediated by visuospatial STM and by visuospatial $\mathrm{WM}(\beta=.18, p=.01)$. On the other hand, visuospatial WM also had a significant indirect effect on $\mathrm{g}$ mediated by visuospatial STM $(\beta=.48, p=.01)$.

\section{Discussion}

The aim of Study 2 was to study the relationship between the visuospatial components of WM (the visuospatial sketchpad and the central executive when it is participating in a visuospatial concurrent processing task) and processing speed, with intelligence. For this purpose, a visuospatial WM battery (BIMeT-VE) was previously developed and validated on a 212 college students sample (Study 1). On the main study (Study 2), 114 college students were assessed. 


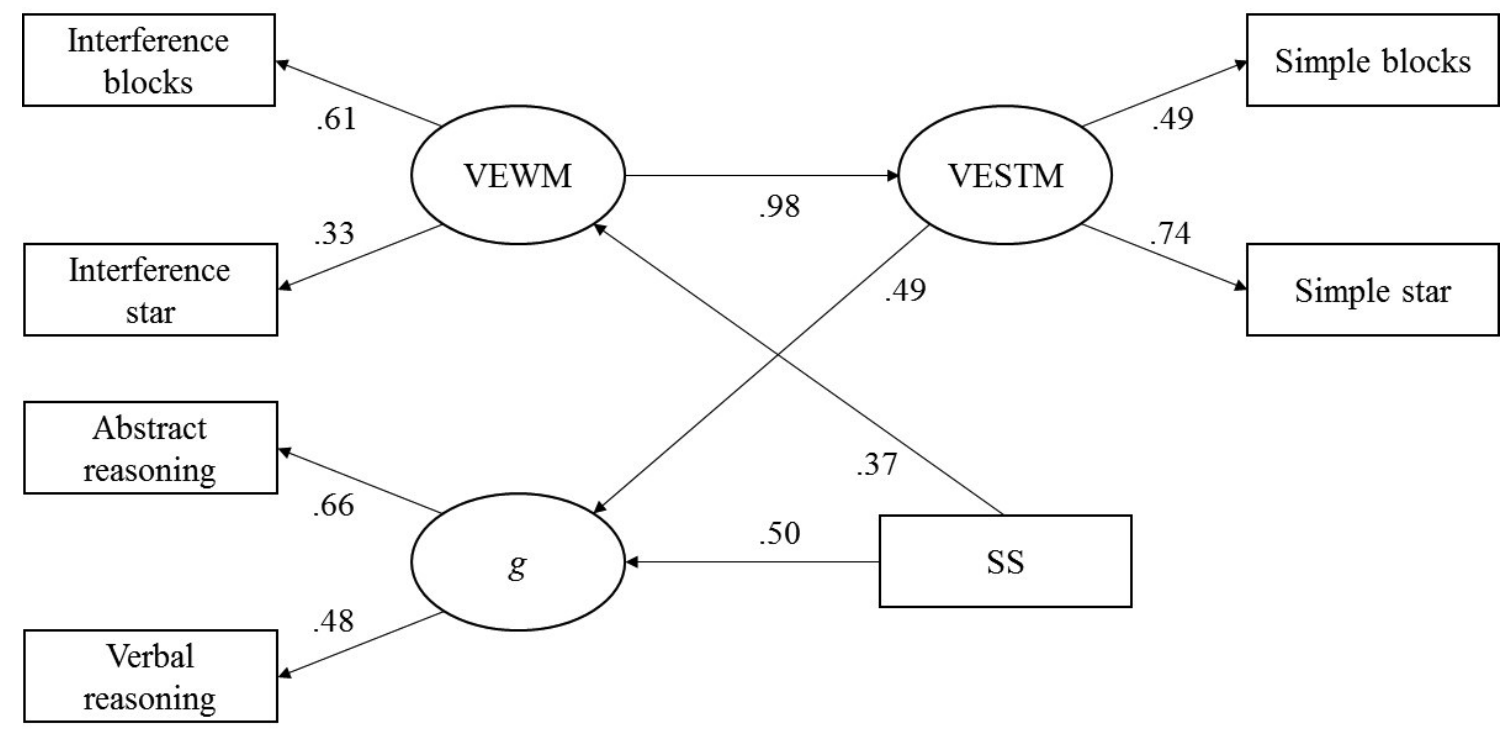

Figure 3.Standardized regression weights and factor loadings on the full SEM model between processing speed, visuospatial short term memory, visuospatial WM and g.

In Study 2, two models of relations between visuospatial WM, visuospatial STM, processing speed and $\mathrm{g}$ were proposed. These models resume the results found in study by Injoque-Ricle et al. (2015) in which the relationship between all components of WM and $g$ was analyzed, and were found a significant direct effect on the relationship between visuospatial STM and g, and an indirect effect on the relation of visuospatial WM and g, mediated by visuospatial STM, but no significant relations was found between verbal components of WM and $\mathrm{g}$.

The first model tested in Study 2 proposed that the visuospatial STM -measured through tests for the visuospatial sketchpad- mediates the relationship between visuospatial WM-measured through visuospatial tests for the central executive- and g, and that processing speed had a direct relation with the rest of the variables.

While this model was significant, the association between processing speed and visuospatial WM and visuospatial STM were not. Therefore, in order to determine whether the relationship found between processing speed and the two aspects of visuospatial WM is accurate, or if is being underlined by the number of related variables, a second model was proposed. In this model processing speed only relates directly with visuospatial WM and $\mathrm{g}$, and its relation with visuospatial STM is mediated by visuospatial WM.

This second model also fitted to the data, and there were no significant differences between this one and Model 1. Therefore, following the principle of parsimony, which states that in similar circumstances the simplest explanation is usually the right one, the model that best describes the relation between the variables is Model 2. Regarding processing speed, and in terms of the strength of the relation, the model indicates that, in the relation of these four variables, it has a moderate relation with $\mathrm{g}$ and a slightly less strong relationship with visuospatial $\mathrm{WM}$, and an association with the visuospatial STM that is mediated by the visuospatial WM.

These results indicate that the ability to properly understand and assimilate information in young adults is directly supported by the ability to sustain the focus of attention on a stimulus or task and, also, by the ability to keep visuospatial information for a short period of time, and indirectly by the ability to process information while it is stored on STM.

\section{General Discussion}

WM is an active memory system serving the realization of complex cognitive tasks (Bad- 
deley, 2010; Shah \& Miyake, 1999). According to Baddeley's classical model (Baddeley, 2010; Baddeley \& Hitch, 1974) it consists of three subsystems: An a modal system in charge coordinating and monitoring the processes necessary to carry out the tasks developed in the WM, called central executive, a temporary store of visual and spatial information, called visuospatial sketchpad and a temporal information store based on language, called phonological loop.

Processing speed is a basic cognitive process that refers to the ease and fluency with which the person responds (Posner, 1975; Posner \& Rothbart, 1998) and is important for the performance of any non-automated task.

The general aim of this paper is to analyze the relation between visuospatial WM, processing speed and intelligence, and the possible mediation role of some of these variables. To carry out this work, a Spanish visuospatial WM battery was designed and validated: the BIMeT-VE. Results from the validation process showed that the BIMeT-VE assesses two visuospatial WM components: an executive component, in which the tasks Interference blocks and Interference star are grouped, and a storage component, in which Simple blocks and Simple star are grouped. Both exploratory and confirmatory factor analyses indicated that the proposed model has a good fit to the sample data. On the other side, Study 2 examined the relationship between the visuospatial components of WM (the visuospatial sketchpad and the central executive when it is participating in a visuospatial concurrent processing task) and processing speed, with intelligence. Results revealed that processing speed has both a direct effect and an indirect effect on $\mathrm{g}$, this last one mediated by visuospatial short term memory and by visuospatial WM. Processing speed also has a direct effect on the performance on visuospatial WM tasks and an indirect effect on visuospatial STM tasks, mediated by visuospatial WM. This implicates that the storage and concurrent processing capacity of visuospatial WM partially mediates the relationship between the ease and fluency of a response to a visuospatial stimulus and general intelligence. Visuospatial WM also has an indirect effect on general intelligence, mediated by visuospatial STM, indicating that the ability to sustain information while a concurrent task is being performed is tightly associated to general intelligence.

The present results are in line with previous findings. Injoque-Ricle et al. (2015) performed a research with college students, and tested the relationship between all components of WM and $\mathrm{g}$, but not processing speed. They found a significant direct effect on the relationship between visuospatial STM and g, and an indirect effect on the relation of visuospatial WM and g, mediated by visuospatial STM, but no significant relations were found between verbal components of WM and g. Their results regarding visuospatial WM and $\mathrm{g}$ are the same as the results found on Study 2. Fry and Hale (1996) using a path analysis studied the relationship between WM, processing speed and fluid intelligence on children, adolescents and young adults, finding that developmental changes in processing speed and WM mediated almost $50 \%$ of changes in fluid intelligence, concluding that individual differences in processing speed have a direct effect on WM capacity, and that this is a direct determinant of individual differences in fluid intelligence. This results are in accordance with those found on Study 2, although WM was included in the model as a single factor, without considering the components of this memory system, but including both verbal and visuospatial WM tasks.

Following Fry and Hale (1996) and InjoqueRicle et al. (2015), a study limitation is the absence of the verbal aspects of WM to study its relation with processing speed and to explore if verbal WM has any mediation effect between processing speed and $g$.

\section{References}

Ackerman, P. L., Beier, M. E., \& Boyle, M. O. (2005). Working memory and intelligence: The same or different constructs? Psychological Bulletin, 131(1), 30-60. doi:10.1037/0033-2909.131.1.30

Alloway, T. P., Gathercole, S. E., Kirkwood, H., \& Elliott, J. (2009). The cognitive and behavioral characteristics of children with low working memory. Child Development, 80(2), 606-621. doi:10.1111/j.1467-8624.2009.01282.x 
American Educational Research Association, American Psychological Association, \& National Council on Measurement in Education. (2000). Standards for Educational and Psychological Testing. Washington, DC: American Educational Research Association.

Baddeley, A. D. (2003). Working memory and language: An overview. Journal of Communication Disorders, 36, 189-208. doi:10.1016/S00219924(03)00019-4

Baddeley, A. D. (2007). Working memory, thought, and action. Oxford, UK: Oxford University Press.

Baddeley, A. D. (2010). Working memory. Current Biology, 20(4), 136-140. doi:10.1016/j. cub.2009.12.014

Baddeley, A. D., Gathercole, S. E., \& Papagno, C. (1998). The phonological loop as a language learning device. Psychological Review, 105, 158-173. doi:10.1037/0033-295X.105.1.158

Baddeley, A. D., \& Hitch, G. J. (1974). Working memory. In G. H. Bower (Ed.), The Psychology of Learning and Motivation: Advances in Research and Theory (Vol. 8, pp. 47-90). New York: Academic Press.

Bennett, G. K., Seashore, H. G., \& Wesman, A. G. (1992). Tests de Aptitudes Diferenciales. Buenos Aires: Paidós.

Broadway, J. M., \& Engle, R. W. (2010). Validating running memory span: Measurement of working memory capacity and links with fluid intelligence. Behavior Research Methods, 42(2), 563 570. doi:10.3758/BRM.42.2.563

Browne, M. W., \& Cudeck, R. (1993). Alternative way of assessing model fit. In K. A. Bollen \& J. S. Long (Eds.), Testing structural equation models. Newbury Park, UK: Sage.

Buehner, M., Krumm, S., Ziegler, M., \& Pluecken, T. (2006). Cognitive abilities and their interplay: Reasoning, crystallized intelligence, working memory components, and sustained attention. Journal of Individual Differences, 27(2), 57-72. doi:10.1027/1614-0001.27.2.57

Bull, R., Espy, K. A., \& Wiebe, S. A. (2008). Shortterm memory, working memory, and executive functioning in preschoolers: Longitudinal predictors of mathematical achievement at age 7 years. Developmental Neuropsychology, 33(3), 205-228. doi:10.1080/87565640801982312
Cain, K., Bryan, P., \& Oakhill, J. (2004). Children's reading comprehension ability: Concurrent prediction by working memory, verbal ability, and component skills. Journal of Educational Psychology, 96, 31-42. doi:10.1037/00220663.96.1.31

Colom, R., Abad, F. J., Quiroga, M. A., Shih, P. C., \& Flores-Mendoza, C. (2008). Working memory and intelligence are highly related constructs, but why? Intelligence, 36, 584-606. doi:10.1016/j. intell.2008.01.002

Colom, R., Rebollo, I., Palacios, A., Juan-Espinosa, M., \& Kyllonen, P. C. (2004). Working memory is (almost) perfectly predicted by $g$. Intelligence, 32(277-296). doi:10.1016/j.intell.2003.12.002

Conway, A. R. A., Cowan, N., Bunting, M. F., Therriault, D. J., \& Minkoff, S. R. B. (2002). A latent variable analysis of working memory capacity, short-term memory capacity, processing speed, and general fluid intelligence. Intelligence, 30, 163-183. doi:10.1016/S0160-2896(01)00096-4

Conway, A. R. A., Kane, M. J., \& Engle, R. W. (2003). Working memory capacity and its relation to general intelligence. Trends in Cognitive Sciences, 7, 547-552. doi:10.1016/j. tics.2003.10.005

Corsi, P. M. (1972). Human memory and the medial temporal region of the brain. Montreal: McGill University Press.

Cowan, N. (2010). The magical mystery four: How is working memory capacity limited, and why? Current Directions in Psychological Science, 19(1), 51-57. doi:10.1177/0963721409359277

Currie, N. K., \& Cain, K. (2015). Children's inference generation: The role of vocabulary and working memory. Journal of Experimental Child Psychology, 137, 57-75. doi:10.1016/j. jecp.2015.03.005

Daneman, M., \& Carpenter, P. A. (1980). Individual differences in working memory and reading. Journal of Verbal Learning and Verbal Behavior, 19, 450-466. doi:10.1016/S00225371(80)90312-6

Daneman, M., \& Merikle, P. M. (1996). Working memory and language comprehension: A metaanalysis. Psychonomic Bulletin \& Review, 3, 422-433. doi:10.3758/BF03214546

Daneman, M., \& Tardif, T. (1987). Working memory and reading skill reexamined. In $\mathrm{M}$. Coltheart 
(Ed.), Attention and performance XII: The psychology of reading. Hillsdale, NJ: Erlbaum.

DeStefano, D., \& LeFevre, J. A. (2004). The role of working memory in mental arithmetic. European Journal of Cognitive Psychology, 16, 353386. doi:10.1080/09541440244000328

Engle, R. W. (2002). Working memory capacity as executive attention. Current Directions in Psychological Science, 11, 19-23. doi:10.1111/14678721.00160

Engle, R. W., Cantor, J., \& Carullo, J. J. (1992). Individual differences in working memory and comprehension; A test of four hypotheses. Journal of Experimental Psychology: Learning, Memory, and Cognition, 18, 972-992. doi:10.1037/02787393.18.5.972

Engle, R. W., Kane, M. J., \& Tuholski, S. W. (1999). Individual differences in working memory capacity and what they tell us about controlled attention, general fluid intelligence and functions of the prefrontal cortex. In A. Miyake \& P. Shah (Eds.), Models of working memory: Mechanisms of active maintenance and executive control (pp. 102-134). London: Cambridge Press.

Evans, J. D. (1996). Straightforward statistics for the behavioral sciences. Pacific Grove, CA: Brooks/ Cole.

Fry, A. F., \& Hale, S. (1996). Processing speed, working memory, and fluid intelligence: Evidence for a developmental cascade. Psychological Science, 7, 237-241. doi:10.1111/j.1467-9280.1996. tb00366.x

Fürst, A. J., \& Hitch, G. J. (2000). Separate roles for executive and phonological components of working memory in mental arithmetic. Memory \& Cognition, 28 (5), 774-782. doi:10.3758/ BF03198412

Garlick, D., \& Sejnowski, T. J. (2006). There is more to fluid intelligence than working memory capacity and executive function. Behavioral and Brain Sciences, 29(2), 134-135. doi:10.1017/ S0140525X0630903X

Gathercole, S. E., Alloway, T. P., Willis, C., \& Adams, A. (2006). Working memory in children with reading disabilities. Journal of Experimental Child Psychology, 93, 265-281. doi:10.1016/j.jecp.2005.08.003

Gathercole, S. E., \& Baddeley, A. D. (2014). Working memory and language. East Sussex, UK: Psychology Press.
Haavisto, M. L., \& Lehto, J. E. (2004). Fluid/spatial and crystallized intelligence in relation to domain-specific working memory: A latent-variable approach. Learning and Individual Differences, 15, 1-21. doi:10.1016/j.lindif.2004.04.002

Hair, F., Anderson, R. E., Tatham, R. L., \& Black, W. C. (1998). Multivariate data analysis with readings. New Jersey, NJ: Prentice Hall.

Hechet, S. A. (2002). Counting on working memory in simple arithmetic when counting is used for problem solving. Memory \& Cognition, 30, 447455. doi:10.3758/BF03194945

Hu, L., \& Bentler, P. M. (1999). Cut-off criteria for fit indexes in covariance structure analysis: Conventional criteria versus new alternatives. Structural Equation Modeling, 6(1), 1-55. doi:10.1080/10705519909540118

Hubber, P. J., Gilmore, C., \& Cragg, L. (2014). The roles of the central executive and visuospatial storage in mental arithmetic: A comparison across strategies. Quarterly Journal of Experimental Psychology, 67(5), 936-954. doi:10.108 $0 / 17470218.2013 .838590$

Injoque-Ricle, I., Barreyro, J. P., Formoso, J., \& Burin, D. I. (2015). Estructura de la memoria de trabajo en jóvenes adultos y su relación con "g". Revista Latinoamericana de Ciencia Psicológica, 7(3), 406-417. doi:10.5872/psiencia/7.3.22

Jensen, A. R. (1998). The g factor: The science of mental ability. Westport, CT: Praeger.

Just, M. A., \& Carpenter, P. A. (1992). A capacity theory of comprehension: Individual differences in working memory. Psychological Review, 99(1), 122-149. doi:10.1037/0033-295X.99.1.122

Kail, R., \& Salthouse, T. A. (1994). Processing speed as a mental capacity. Acta Psychologica, 86, 199-225. doi:10.1016/0001-6918(94)90003-5

Kane, M. J., \& Engle, R. W. (2002). The role of prefrontal cortex in working memory capacity, executive attention, and general fluid intelligence: An individual-differences perspective. Psychonomic Bulletin \& Review, 9(4), 637-671. doi:10.3758/BF03196323

Kyllonen, P. C., \& Christal, R. E. (1990). Reasoning ability is (little more than) working memory capacity?! . Intelligence, 14, 389-433. doi:10.1016/ S0160-2896(05)80012-1

Oakhill, J. V., Hartt, J., \& Samols, D. (2005). Comprehension monitoring and working memory 
in good and poor comprehenders. Reading and Writing, 18, 657-686. doi:10.1007/s11145-005$3355-\mathrm{z}$

Oberauer, K., Süb, H. M., Wilhelm, O., \& Wittmann, W. W. (2008). Which working memory functions predict intelligence? Intelligence, 36, 641652. doi:10.1016/j.intell.2008.01.007

Posner, M. (1975). The psychobiology of attention. In M. A. Gazzaniga \& C. Blakemore (Eds.), Handbook of Psychobiology. New York: Academic Press.

Posner, M. I., \& Boies, S. J. (1971). Components of attention. Psychological Review, 78(5), 391408. http://dx.doi.org/10.1037/h0031333

Posner, M., \& Rothbart, M. K. (1998). Attention, self-regulation, and consciousness. Philosophical Transactions of the Royal Society of London, B(353), 1915-1927. doi:10.1098/rstb.1998.0344

Preacher, K. J., \& Hayes, A. F. (2008). Asymptotic and resampling strategies for assessing and comparing indirect effects in multiple mediator models. Behavior Research Methods, 40(3), 879-91. doi:10.3758/BRM.40.3.879

Schumacker, R. E., \& Lomax, R. G. (1996). A beginner guide to structural equation modeling. Mahwah, NJ: Erlbaum.

Shah, P., \& Miyake, A. (1996). The separability of working memory resources of spatial thinking and language processing: An individual differences approach. Journal of Experimental Psychology: General, 125, 4-27. doi:10.1037/00963445.125.1.4

Shah, P., \& Miyake, A. (1999). Models of working memory: An introduction. In A. Miyake \& P. Shah (Eds.), Models of working memory (pp. 1-27). Cambridge, MA: Cambridge University Press.

Sohlberg, M. M., \& Mateer, C. A. (1989). Introduction to Cognitive Rehabilitation. New York: The Guilford Press.
Spearman, C. (1904). "General intelligence," objectively determined and measured. American Journal of Psychology, 15, 201-293. doi: $10.2307 / 1412107$

Süb, H. M., Oberauer, K., Wittmann, W. W., Wilhelm, O., \& Schulze, R. (2002). Working-memory capacity explains reasoning ability and a little bit more. Intelligence, 30, 261-288.

Unsworth, N., \& Engle, R. W. (2005). Working memory capacity and fluid abilities: Examining the correlation between operation span and Raven. Intelligence, 33, 67-81. doi:10.1016/j. intell.2004.08.003

Unsworth, N., Fukuda, K., Awh, E., \& Vogel, E. K. (2014). Working memory and fluid intelligence: Capacity, attention control, and secondary memory retrieval. Cognitive Psychology, 71, 1-26. doi:10.1016/j.cogpsych.2014.01.003

Unsworth, N., Redick, T. S., Heitz, R. P., Broadway, J. M., \& Engle, R. W. (2009). Complex working memory span tasks and higher-order cognition: A latent-variable analysis of the relationship between processing and storage. Memory, 17(6), 635-654. doi:10.1080/09658210902998047

Van Dyke, J. A., Johns, C. L., \& Kukona, A. (2014). Low working memory capacity is only spuriously related to poor reading comprehension. Cognition, 131(3), 373-403. doi:10.1016/j.cognition.2014.01.007

Wechsler, D. (2003). WAIS III: Test de Inteligencia para Adultos. Buenos Aires: Paidós.

Zillmer, E. A., \& Spiers, M. V. (1998). Principles of clinical neuropsychology. Pacific Groove, CA: Brooks/Cole.
Received: 05/07/2016

$1^{\text {st }}$ revision: 07/11/2016

$2^{\text {nd }}$ revision: 07/02/2017

$3^{\text {rt }}$ revision: $27 / 02 / 2017$

Aceite final: 10/03/2017

(C) The Author(s), 2018. Open Access. This article is distributed under the terms of the Creative Commons Attribution 4.0 International License (http://creativecommons.org/licenses/by/4.0/), which permits unrestricted use, distribution, and reproduction in any medium, provided you give appropriate credit to the original author(s) and the source, provide a link to the Creative Commons license, and indicate if changes were made. 